\title{
Severe acute respiratory syndrome: clinical features
}

Princess Margaret Hospital SARS Study Group: Po Oi Lee, Ping Tim Tsui, Tak Yin Tsang, Tai Nin Chau, Chi Pong Kwan, Wai Cho Yu, Sik To Lai

Department of Medicine \& Geriatrics, 2-10 Princess Margaret Hospital Road, Hong Kong Special Administrative Region, China

\section{Introduction}

The incubation period of severe acute respiratory syndrome (SARS) ranges from 2 to 10 days. The clinical features and key laboratory parameters on presentation are summarised in Tables 1 and 2. The majority of patients with SARS present with abrupt onset of high fever of more than $38^{\circ} \mathrm{C}$ with or without chills. Flu-like symptoms of malaise, myalgia, headache and dizziness are rather common. While the respiratory system is predominantly affected, other organs are also involved.

\section{Respiratory tract}

Many SARS patients do not have upper respiratory tract symptoms of sore throat or running nose. Cough may not be present even in patients with radiological evidence of pneumonitis and is usually not associated with sputum production. Some of them may already have shortness of breath and tachypnoea on presentation. Chest sign is usually minimal. Inspiratory crackles may be heard at lung bases. Chest radiography is the primary imaging tool for diagnosis and follow up assessment of treatment response. High resolution computer tomography (HRCT) of the thorax is performed when initial chest radiograph is negative despite high clinical suspicion. It is also helpful in detecting complication and in defining nature and extent of lung damage.

\section{Chest radiography}

Chest radiography can serve as a screening tool in the correct clinical setting. In a prospective study conducted in a SARS screening clinic for hospital staff, patients and their relatives, chest radiological changes were 
found to have the highest odds ratio of all the predictors [7]. The authors concluded that chest radiography should be mandatory for all patients screened for the disease. At the peak of the epidemic, patients with flu-like symptoms attending outpatient clinic were asked to take a chest radiograph before being interviewed for history-taking and physical examination [8].

Most patients have abnormal chest radiographs on presentation. Lee et al. noted that $78 \%$ of SARS patients had abnormal chest radiographs at the onset of fever, all showing air-space consolidation [4]. In a cluster of 10 epidemiologically linked patients, all except one showed abnormal initial chest radiographs [9]. In another retrospective study of 51 patients with probable SARS, abnormal findings were noted in $80 \%$ of initial chest films [10].

The initial changes are indistinguishable from those with other causes of atypical or viral pneumonia. All patients with abnormal initial chest radiograph present with air-space opacification $[4,9,10]$. This can be focal, unilateral or bilateral multifocal involvement (Fig. 1). The lower zones and peripheral lung fields are commonly affected $[4,11]$. Grinblat et al. reported similar findings of predominant peripheral consolidation in middle and lower zones in a review of 40 patients in Toronto [12]. Relevant negative findings are lack of cavitation, calcification, reticular or nodular pattern of opacification and pleural effusion.

For those with normal initial chest radiographs, follow-up films were found to become abnormal after an average of 3 days [7]. It can however remain falsely negative until late in the course of the disease [13].

Serial radiographs showed one of the four patterns in the review by Antonio et al. [7]:

1. Appearance deteriorates for a week followed by improvement in $70.3 \%$.

2. Appearance fluctuates with at least one intervening period of significant improvement followed by deterioration and later recovery in $17.4 \%$.

3. Relatively static for 10 days followed by improvement in $7.2 \%$.

4. Progressive deterioration leading to death in $5.1 \%$.

Radiographic deterioration takes on the form of multifocal unilateral or bilateral opacification in most patients. Resolution of lung opacities can be demonstrated with successful treatment response. Confluent consolidation compatible with adult respiratory distress syndrome (ARDS) is associated with a grave prognosis.

\section{$H R C T$}

Both conventional CT and HRCT have been performed on patients with suspected SARS early in the outbreak. Only HRCT is now required with increasing knowledge on the radiographic and CT features of the disease. It can reveal parenchymal disease in patients whose radiographs are nor- 


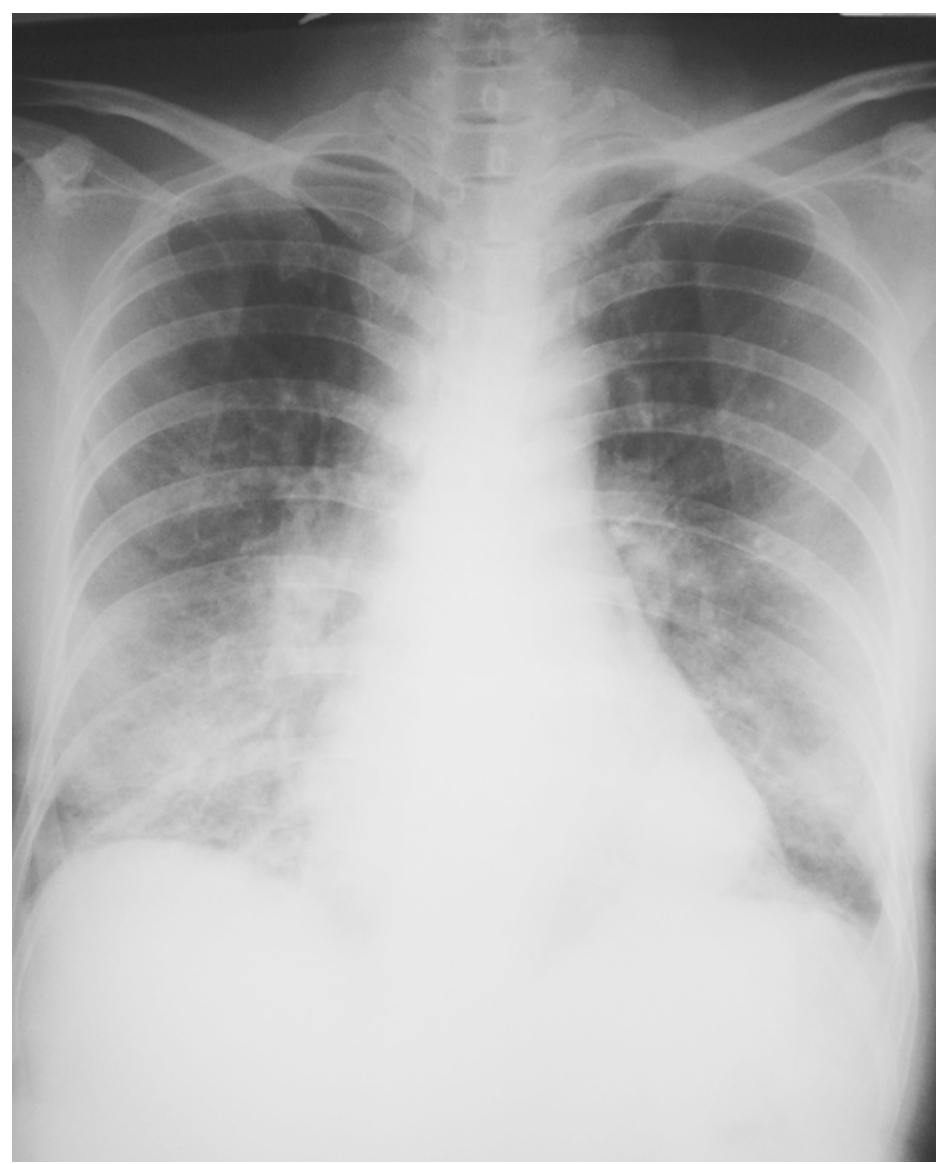

Figure 1. Frontal chest radiograph showing bilateral multifocal consolidation in lower zones

mal $[13,14]$. The abnormality can either be very small, or in the paraspinal region hidden by the heart or mediastinal structures, or in the posterior costophrenic angles [7].

Lee et al. reviewed the CT findings in 25 patients [4]. The typical finding was ill defined ground glass opacification in the periphery usually in a subpleural location, an appearance similar to that seen in bronchiolitis obliterans organizing pneumonia (BOOP). No bronchial dilatation was noted. Wong et al. reviewed the $\mathrm{CT}$ findings in 73 patients exposed to or with the disease [15]. Common findings included ground glass opacification, sometimes with consolidation, interlobular septal and intralobular interstitial thickening (Fig. 2). Lower lobe and peripheral distribution were again noted. Cavitation, calcification, reticular or nodular pattern of opacification, lymphadenopathy, or pleural effusion are not features of this disease [7]. 


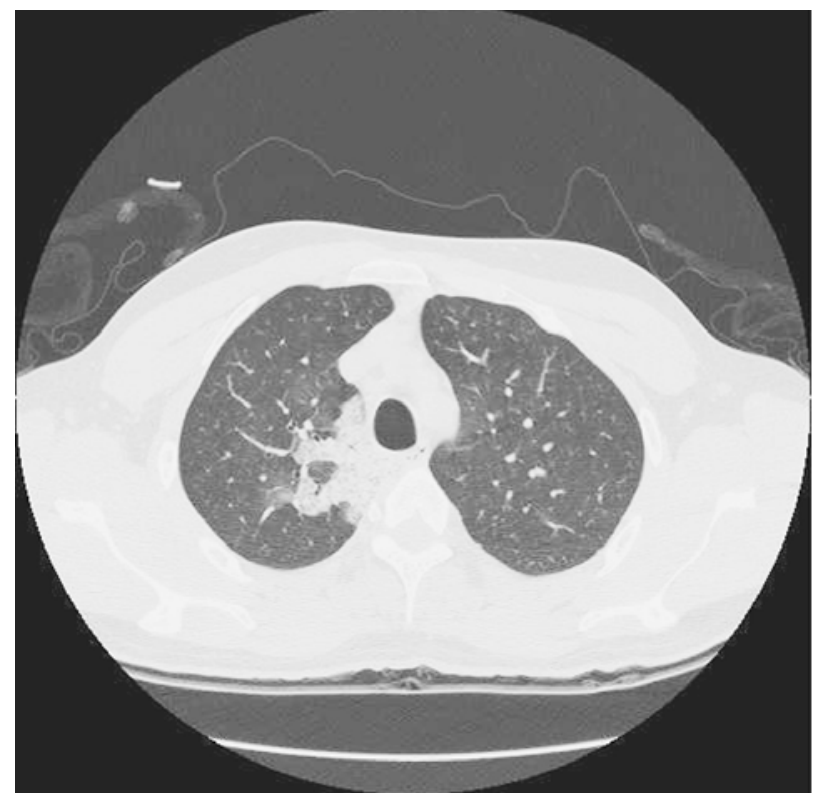

Figure 2. High resolution computed tomography of thorax showing consolidation in right upper lobe

Chan et al. reviewed the HRCT findings in 27 patients [16]. Ground glass density and crazy paving pattern were found to be the key features in the first week of the disease. The ground glass opacity could be as small as $5 \mathrm{~mm}$, and in a perihilar, central or peripheral location. Crazy paving pattern which consisted of thin reticular shadow superimposed on ground glass opacity, again showed no specific pattern of distribution. Other findings included a sharp line of demarcation between normal and abnormal lungs, and subpleural sparing. Small localized pleural effusion was noted in 7 out of 27 patients $(25.9 \%)$, usually with extensive disease.

Serial HRCT show a shifting pattern of air-space opacification, with resolution of the original lesion and appearance of a new lesion in the adjacent lung [17]. Progressive decrease in the extent of ground glass opacity and consolidation occurs with resolution of symptoms. Spontaneous pneumomediastinum is found in a substantial proportion of patients, usually during or just after completion of drug treatment [16-18]. This is unrelated to the use of positive end-expiratory pressure ventilation. Possible causes like peribronchiolar abscess formation leading to interstitial pulmonary emphysema, and the presence of subpleural blebs have been proposed. Subcutaneous emphysema and pneumothorax may develop as a result of pneumo-mediastinum.

Findings consistent with fibrosis have been described in a small percentage of patients $[17,18]$. Muller et al. reviewed the HRCT findings in 29 
patients [18]. Reticulation with associated architectural distortion and traction bronchiectasis was present in eight patients. The longest follow up HRCT was 27 days after hospital admission. Further follow up is required to determine whether these changes are reversible.

The role of imaging is to provide radiological evidence for diagnosis and to monitor disease progress and treatment response. The radiographic and CT appearances are not specific and clinical information is vital in establishing the diagnosis. HRCT should be limited to patients with high clinical suspicion and normal chest radiographs, and for detecting complications. While radiography is routinely performed using a portable machine at the bedside, CT scanners are often located in the main radiology department. Strict infection control is necessary to minimize cross infection. Mobile CT may be an alternative for seriously ill patients requiring strict isolation during an outbreak [19].

\section{Gastrointestinal tract}

Gastrointestinal symptoms of nausea, vomiting and diarrhea may be prominent presenting features of SARS (Tab. 1). Diarrhea is common (38-73\%) during the whole course of illness $[3,5,20]$. It is more frequently observed during the first week of illness and usually self limiting [20]. Some patients may have protracted diarrhea leading to dehydration. Cheng et al. found that higher viral load in nasopharyngeal specimens was significantly associated with diarrhea and death [21].

There are other possible explanations of the high incidence of diarrhea reported in SARS. Most SARS patients in Hong Kong received a course of amoxicillin/clavulanic acid, clarithromycin and ribavirin, which had been reported to cause diarrhea. In studies using a combination of amoxicillin and clarithromycin for one week to eradicate Helicobacter pylori, diarrhea was reported in 3-34\% of cases [22-24]. Clostridium difficile toxin could not be detected in stool of SARS patients treated with broad spectrum antibiotics [20].

Coronaviruses are a diverse group of enveloped RNA viruses that are known to cause a wide spectrum of diseases including respiratory and gastrointestinal systems in animals. Enteric coronavirus has been described to cause diarrhea in children and subjects with acquired immunodeficiency syndrome [25]. Recently, Leung et al. reported histological features of five post-mortem examinations of bowel and one colonic biopsy in SARS patients [20]. Light microscopic results were unremarkable with little inflammatory changes. Electron microscopy showed presence of virus particles in dilated endoplasmic reticulum and on the luminal surface of microvilli. This suggests viral shedding into the lumen of the gastrointestinal tract. SARS-associated coronavirus (SARS-CoV) could also be isolated from intestinal tissue by cell culture. Nonetheless, in view of the limited 
Table 1. Clinical features of SARS on presentation

\begin{tabular}{lcc}
\hline & Donnelly et al. [1] & Booth et al. [2] \\
\hline Number of patients & 1425 & 144 \\
Fever (\%) & 94 & 99 \\
Chills (\%) & 65 & 28 \\
Malaise (\%) & 64 & NR \\
Myalgia (\%) & 51 & 49 \\
Headache (\%) & 50 & 35 \\
Dizziness (\%) & 31 & NR \\
Sore throat (\%) & 23 & 13 \\
Running nose (\%) & 25 & 2 \\
Cough (\%) & 50 & 69 \\
Sputum production (\%) & 28 & 5 \\
Shortness of breath (\%) & 31 & NR \\
Nausea (\%) & 22 & NR \\
Vomiting (\%) & 14 & 24 \\
Diarrhea (\%) & 27 &
\end{tabular}

NR, not reported

architectural disturbance, there is still no solid evidence that the SARS$\mathrm{CoV}$ is the cause of diarrhea. Protein or toxins released from SARS-CoV was postulated to cause diarrhea but this theory remains speculative [20]. The gastrointestinal tract is the only organ other than the lungs where SARS-CoV could be isolated by cell culture.

Diarrhea poses a significant infection control problem because SARSCoV RNA can be identified in stool of a majority of cases [5]. Although stool culture for SARS-CoV has not been successful, fecal-oral transmission of SARS-CoV remains a distinct possibility. The outbreak of SARS in a densely populated private housing complex of Hong Kong was traced to a 33 year-old SARS patient with watery diarrhea. It was postulated that the virus-laden aerosols were spread via a faulty sewage system [26].

\section{Liver}

Twenty-three to $35 \%$ of patients had an elevated alanine transaminase on presentation (Tab. 2). Wong et al. reported a drop of albumin level and an elevation of globulin and serum bilirubin levels on serial measurements [27]. Seventy-six percent of patients developed liver dysfunction during the course of illness. They also found that the time to peak of alanine transaminase or bilirubin level correlated with the time to worst chest radiographic scores. These findings were not shared by the control group of age- and sex-matched patients with community-acquired pneumonia. Tsang et al. reported that higher alanine transaminase levels were found among patients with positive reverse transcriptase-polymerase chain reaction (RTPCR) for SARS-CoV in nasopharyngeal aspirate [28]. This suggests a rela- 
Table 2. Key laboratory findings of SARS at presentation

\begin{tabular}{lccccc}
\hline & $\begin{array}{c}\text { Choi et al. } \\
{[3]}\end{array}$ & $\begin{array}{c}\text { Booth et al. } \\
{[2]}\end{array}$ & $\begin{array}{c}\text { Lee et al. } \\
{[4]}\end{array}$ & $\begin{array}{c}\text { Peiris et al. } \\
{[5]}\end{array}$ & $\begin{array}{c}\text { Vu et al. } \\
{[6]}\end{array}$ \\
\hline Number of patients & 267 & 144 & 138 & 75 & 62 \\
Leucopenia (\%) & 27 & NR & 34 & 7 & 19 \\
Lymphopenia (\%) & 73 & 85 & 70 & 75 & 79 \\
Thrombocytopenia (\%) & 50 & NR & 45 & 37 & 40 \\
Hyponatraemia (\%) & NR & NR & 20 & NR & 30 \\
Elevated ALT (\%) & 31 & NR & 23 & 29 & 35 \\
Elevated CK (\%) & 19 & 39 & 32 & 36 & NR \\
Elevated LDH (\%) & 47 & 87 & 71 & NR & NR \\
\hline
\end{tabular}

ALT, alanine transaminase; CK, creatine kinase; LDH, Lactate dehydrogenase; NR, not reported

tionship between hepatic dysfunction and viral load. SARS-CoV is a novel virus of which hepatotropism is unknown. Mouse hepatitis virus, a group 2 coronavirus, can cause liver damage ranging from minimal change to fulminant hepatitis. Liver histology provides important clues as to the cause of liver dysfunction. Autopsy findings of SARS patients showed features of fibrinoid necrosis, and infiltration of monocytes and lymphocytes into the vessel, suggestive of systemic vasculitis while others showed apoptosis and fatty degeneration in liver. However, most of these findings belonged to patients with respiratory failure and multi-organ failure, hence the changes in the liver might not be solely due to SARS-CoV. Chau et al. reported liver biopsy results of three patients with marked hepatic dysfunction [29]. Prominent mitotic figures of hepatocytes were noted in two and apoptosis in all three patients. Conspicuous mitosis may be related to cell cycle arrest as a result of SARS-CoV infection. Furthermore, RT-PCR also showed evidence of SARS-CoV in liver tissues, though electron microscopy could not identify viral particles.

\section{Hematology system}

The majority of patients presented with lymphopenia with normal or low total white cell count (Tab. 2). Wong et al. found that both CD4 and CD8 lymphocytes were depleted on presentation while their ratio remained normal [30]. The B lymphocytes counts were normal. The lymphocyte counts might further fall or remain low as the disease progressed and 153 out of $157(98 \%)$ patients had lymphopenia during the whole course of illness. On the other hand, thrombocytopenia is also a common presenting feature (Tab. 2). Reactive thrombocytosis may occur in some patients. Lee et al. reported that prolonged activated partial-thromboplastin time and elevated D-dimer levels were found in $43 \%$ and $45 \%$ of patients on presentation, respectively [4]. The prothrombin time remained normal. Both thrombocy- 
topenia and deranged clotting profile did not cause clinically significant bleeding. Neutrophilia may develop and can be partly attributed to the use of steroids and secondary nosocomial infection. Hemoglobin may drop secondary to hemolysis in patients receiving ribavirin.

\section{Other systems}

Both creatine kinase and lactate dehydrogenase may be elevated on presentation and they continue to rise as the disease progresses (Tab. 2). The lactate dehydrogenase level reflects tissue destruction or hemolysis secondary to ribavirin treatment. Wang et al. reported three cases of rhabdomyolysis associated with probable SARS [31]. The patients had very high peak creatine kinase levels and developed myoglobinuria leading to acute renal failure; two of them died. Muscle biopsies showed degenerative changes and necrosis of muscle fibers in the most severe cases. Cardiac-specific troponin levels are usually normal. Sub-clinical diastolic dysfunction without systolic impairment in heart had been reported in SARS and was reversible as the patients recovered [32]. Post-mortem examination did not reveal direct invasion of myocardium by the virus. Lau et al. reported a pregnant woman with SARS who developed generalized convulsion without an obvious explanatory cause [33]. She was found RT-PCR positive for SARS-CoV in cerebrospinal fluid. This raises the possibility of central nervous system invasion by the SARS-CoV. Recent experimental evidence showed neurotropism and neuroinvasion of human coronavirus and its link with multiple sclerosis [34]. Electrolyte disturbances including hypokalemia may develop during the course of illness secondary to diarrhea, use of ribavirin and steroids.

\section{Atypical presentation}

Subclinical infection by SARS-CoV is rare. Lee et al. performed serological screening of asymptomatic healthcare workers who had taken care of SARS patients [35]. Only one out of 101 subjects was tested positive for SARS-CoV. Chow et al. found that none of the 84 exposed healthcare workers in whom SARS did not develop had seroconversion [36]. Mild infection by SARS-CoV without florid pulmonary involvement has been described. Lin et al. reported a 28-year-old physician who had close contact with SARS patients and presented with fever, malaise and myalgia without apparent pneumonitis by chest radiography [37]. His serum was later found to be positive for immunoglobulin $\mathrm{G}$ against SARS-CoV. These findings raise a possibility of genetic predisposition or susceptibility to SARS-CoV infection. Preliminary research by $\mathrm{Li}$ et al. found that the human leukocyte antigen system might be linked to the severity of SARS-CoV infection [38]. 
SARS runs a milder and shorter course in children under the age of 12 [39]. Hon et al. reported that four out of five teenagers but none of the younger children required supplemental oxygen therapy [40]. Two teenagers required assisted ventilation.

Atypical presentation of SARS in geriatric patients is a diagnostic challenge. The clinical picture is often confounded by multiple co-existing diseases that apparently could explain the illnesses [41]. Epidemiological history of contact may not be obvious. Fever may be low grade, self limiting or even absent in elderly patients infected with SARS-CoV. Clinicians may have mistaken spontaneous resolution of fever as response to antibiotics and misdiagnosed SARS as bacterial pneumonia. Cough may be absent because of suppressed cough reflex in elderly.

\section{Clinical course and prognosis}

The clinical outcome and prognostic factors are summarized in Table 3. Peiris et al. found that the viral load peaked at around day 10 after onset of symptoms [5]. The majority of patients had a fall in temperature after ribavirin and steroids combination therapy. However, $85 \%$ of patients developed recurrence of fever and progression of pneumonitis despite fall in viral load; $20 \%$ developed ARDS. Immunological damage secondary to cytokine deregulation was postulated to be the underlying pathogenetic mechanism. Twenty to $34 \%$ of patients were in intensive care while $13-26 \%$ required assisted ventilation (Tab. 3). Non-invasive positive pressure ventilation has been tried successfully in SARS patients, alleviating the need of intubation and mechanical ventilation. Nosocomial chest infection is an important problem in patients who depend on ventilator support and receive steroid therapy. Superinfection with Aspergillus fumigatus was reported in patients receiving high dose steroids with broad-spectrum antibiotics [44]. Acute renal or mutli-organ failure may further complicate the clinical course and compromise the chance of survival in critically ill SARS patients.

The case fatality rate varied widely among different affected regions. According to the World Health Organization (WHO), the overall worldwide case fatality rate was $9.6 \%$ and ranged from 7 to $17 \%$ in individual countries with major outbreak [45]. The rates stated in major published data ranged from 3.6 to $12 \%$. The figures should be interpreted with care. The study populations might not be comparable. Studies with longer follow-up time have higher case fatality rate. The case definition of SARS in many studies was based only on clinical parameters instead of serological criteria. The sensitivity and specificity of the WHO criteria for the diagnosis of SARS-CoV infection was only $26 \%$ and $96 \%$, respectively [46]. The pre-morbid risk profile of SARS patients may also affect the case fatality rate. SARS-CoV could be the principal cause of death or one of the contributing factors in patients with multiple underlying diseases. 


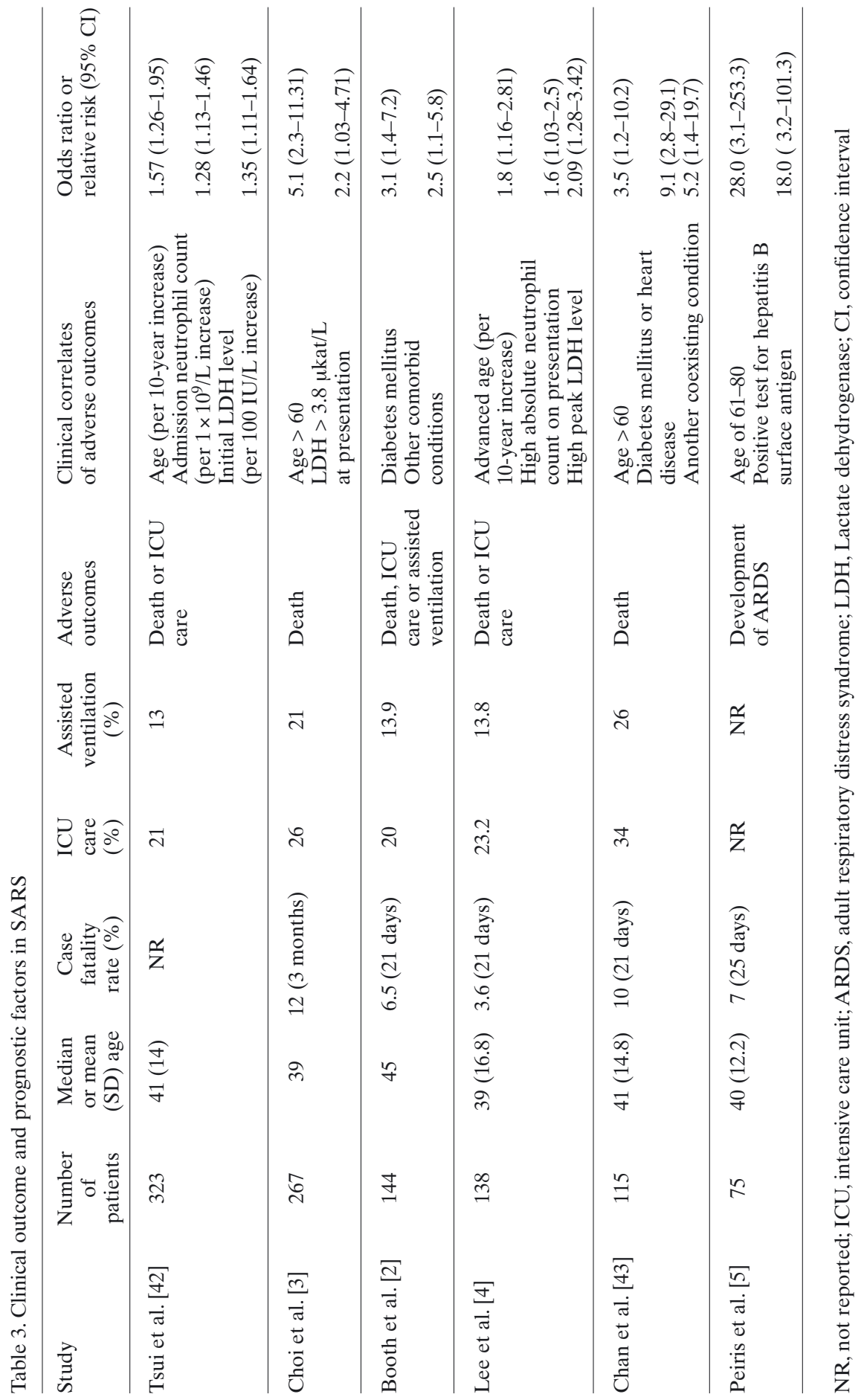




\section{Prognostic factors}

Identification of prognostic factors is key to risk stratification and planning of management in SARS patients, although no treatment has yet been proven in randomized trial to be efficacious in the combat of SARS. Prognostic factors varied among different research centers depending on the variables included under study and case-mix. Advanced age [4, 42], especially those over the age of $60[3,5,43]$, concurrent medical illnesses [2, 43], particularly diabetes mellitus [2,43] are consistently established as independent clinical prognostic indicators for adverse clinical outcomes comprising death, intensive care admission or assisted ventilation (Tab. 3). High neutrophil counts $[4,42]$ and lactate dehydrogenase level $[30,42]$ on presentation, low CD4 and CD8 lymphocyte counts [30], hypoxemia and thrombocytopenia [47] are also associated with poor outcomes.

High viral load [21] or positivity of RT-PCR for SARS-CoV in nasopharyngeal aspirate [28] is also a prognostic factor. The development of quantitative, real-time, nested RT-PCR assay for SARS-CoV in upper respiratory tract or serum offers hope for early detection of SARS and monitoring of viral load $[48,49]$. Higher serum SARS-CoV concentration predicts intensive care unit admission [48].

Chest radiography also carries prognostic information. Paul et al. [10] reviewed the chest radiographs of 51 patients. Four radiographic patterns were seen: normal (group 1) in 19.6\% (10/51), focal opacity (group 2) in $39.2 \%(20 / 51$ ), multifocal opacities (group 3 ) in $27.5 \%$ (14/51), and diffuse air-space opacification (group 4) in 13.7\% (7/51). Radiographic progression occurred in $38.8 \%$ of the patients in group $1-4$. There was no death in group 1 and 2 . Mortality was $7.7 \%$ in group 3 and $71.4 \%$ in group 4 . Diffuse airspace opacification was noted on the last radiographs for all patients who died. The authors concluded that patients presenting with normal findings or focal air-space opacity on chest radiograph had a good clinical outcome. Patients with multifocal opacities that progressed to diffuse opacification and patients presenting with diffuse air-space opacification had a high fatality rate. Chau et al. found that initial chest radiographic score was an independent prognostic factor among the clinical, laboratory and chest radiography variables studied [50].

\section{References}

1 Donnelly CA, Ghani AC, Leung GM, Hedley AJ, Fraser C, Riley S, AbuRaddad LJ, Ho L, Thach T, Chau P et al (2003) Epidemiological determinants of spread of causal agent of severe acute respiratory syndrome in Hong Kong. Lancet 361: 1761-1766

2 Booth CM, Matukas LM, Tomlinson GA, Rachlis AR, Rose DB, Dwosh HA, Walmsley SL, Mazzulli T, Avendano M, Derkach P et al (2003) Clinical features 
and short-term outcomes of 144 patients with SARS in the greater Toronto area. JAMA 289: 2801-2809

3 Choi KW, Chau TN, Tsang O, Tso E, Chiu MC, Tong WL, Lee PO, Ng TK, Ng WF, Lee KC et al (2003) Outcomes and prognostic factors in 267 patients with severe acute respiratory syndrome in Hong Kong. Ann Intern Med 139: $715-723$

4 Lee N, Hui D, Wu A, Chan P, Cameron P, Joynt GM, Ahuja A, Yung MY, Leung CB, To KF et al (2003) A major outbreak of severe acute respiratory syndrome in Hong Kong. N Engl J Med 348: 1986-1994

5 Peiris JS, Chu CM, Cheng VC, Chan KS, Hung IF, Poon LL, Law KI, Tang BS, Hon TY, Chan CS et al (2003) Clinical progression and viral load of coronavirus pneumonia in a community outbreak: a prospective study. Lancet 361 : $1767-1772$

6 Vu HT, Leitmeyer KC, Le DH, Miller MJ, Nguyen QH, Uyeki TM, Reynolds MG, Aagesen J, Nicholson KG, Vu QH et al (2004) Clinical description of a completed outbreak of SARS in Vietnam, February-May 2003. Emerg Infect Dis 10: 334-338

7 Antonio GE, Wong KT, Chu WC, Hui DS, Cheng FW, Yuen EH, Chung SS, Fok TF, Sung JJ, Ahuja AT (2003) Imaging of severe acute respiratory syndrome in Hong Kong. AJR 81:11-17.

8 Young DYN, Lau BWK (2003) An outcome analysis of chest x-ray examination for detecting severe acute respiratory syndrome in general practice. $H K$ Pract 25: 357-362

9 Tsang KW, Ho PL, Ooi GC Yee WK, Wang T, Chan-Yeung M, Lam WK, Seto WH, Yam LY, Cheng TM et al (2003) A cluster of cases of severe acute respiratory syndrome in Hong Kong. N Engl J Med 348: 1977-1985.

10 Paul NS, Chung T, Konen E, Roberts HC, Rao TN, Gold WL, Mehta S, Tomlinson GA, Boylan CE, Grossman H et al (2004) Prognostic significance of the radiographic pattern of disease in patients with severe acute respiratory syndrome. AJR 182: 493-498

11 Wong KT, Antonio GE, Hui DS, Lee N, Yuen EH, Wu A, Leung CB, Rainer TH, Cameron P, Chung SS et al (2003) Severe acute respiratory syndrome: radiographic appearances and pattern of progression in 138 patients. Radiology 228: 401-406

12 Grinblat L, Shulman H, Glickman A, Matukas L, Paul N (2003) Severe acute respiratory syndrome: radiographic review of 40 probable cases in Toronto, Canada. Radiology 228: 802-809

13 Rao TNA, Paul N, Chung TB, Mazzulli T, Walmsley S, Boylan CE, Provost Y, Herman SJ, Weisbrod GL, Roberts HC et al (2003) Value of CT in assessing probable severe acute respiratory syndrome. AJR 181:317-319

14 Muller NL, Ooi GC, Khong PL, Nicolaou S (2003) Severe acute respiratory syndrome: radiographic and CT findings. AJR 181:3-8

15 Wong KT, Antonio GE, Hui DS, Lee N, Yuen EH, Wu A, Leung CB, Rainer TH, Cameron P, Chung SS (2003) Thin-section CT of severe acute respiratory 
syndrome: evaluation of 73 patients exposed to or with the disease. Radiology 228: 395-400

16 Chan MS, Chan IY, Fung KH, Poon E, Yam LY, Lau KY et al (2004) High-resolution CT findings in patients with severe acute respiratory syndrome: a pattern-based approach. AJR 182: 49-56

17 Hui JY, Cho DH, Yang MK, Wang K, Lo KK, Fan WC, Chan CC, Chu CM, Loke TK, Chan JC et al (2003) Severe acute respiratory syndrome: spectrum of high-resolution CT findings and temporal progression of the disease. AJR 181: $1525-1538$

18 Muller NL, Ooi GC, Khong PL, Zhou LJ, Tsang KW, Nicolaou S (2004) Highresolution $\mathrm{CT}$ findings of severe acute respiratory syndrome on presentation and after admission. AJR 182: 39-44

19 Parmar HA, Lim TC, Goh JS, Tan JT, Sitoh YY, Hui F (2004) Providing optimal radiology service in the severe acute respiratory syndrome outbreak: use of mobile CT. AJR 182: 57-60

20 Leung WK, To KF, Chan PK, Chan HL, Wu AK, Lee N, Yuen KY, Sung JJ (2003) Enteric involvement of severe acute respiratory syndrome-associated coronavirus infection. Gastroenterology 125(4): 1011-1017

21 Cheng VC, Hung IF, Tang BS, Chu CM, Wong MM, Chan KH, Wu AK, Tse DM, Chan KS, Zheng BJ et al (2004) Viral replication in the nasopharynx is associated with diarrhea in patients with severe acute respiratory syndrome. Clin Infect Dis 38: 467-475

22 Sung JJ, Chan FK, Wu JC, Leung WK, Suen R, Ling TK, Lee YT, Cheng AF, Chung SC (1999) One-week ranitidine bismuth citrate in combinations with metronidazole, amoxycillin and clarithromycin in the treatment of Helicobacter pylori infection: the RBC-MACH study. Aliment Pharmacol Ther 13(8): 1079-1084

23 Sung JJ, Leung WK, Ling TK, Yung MY, Chan FK, Lee YT, Cheng AF, Chung SC (1998) One-week use of ranitidine bismuth citrate, amoxicillin and clarithromycin for the treatment of Helicobacter pylori-related duodenal ulcer. Aliment Pharmacol Ther 12(8): 725-730

24 Veldhuyzen Van Zanten SJO, Bradette M, Farley A, Leddin D, Lind T, Unge P, Bayerdorffer E, Spiller RC, O'morain C, Sipponen P et al (1999) The DUMACH study: eradication of Helicobacter pylori and ulcer healing in patients with acute duodenal ulcer using omeprazole based triple therapy. Aliment Pharmacol Ther 13(3): 289-295

25 Schmidt W, Schneider T, Heise W, Weinke T, Epple HJ, Stoffler-Meilicke M, Liesenfeld O, Ignatius R, Zeitz M, Riecken EO et al (1996) Stool viruses, coinfections, and diarrhea in HIV-infected patients. Berlin Diarrhoea/Wasting Syndrome Study Group. J Acquir Immune Defic Syndr Hum Retrovirol 13: 33-38

26 Department of Health, HKSAR (2003) Outbreak of severe acute respiratory syndrome (SARS) at Amoy Gardens, Kowloon Bay, Hong Kong. Available from: http://www.info.gov.hk/info/ap/pdf/amoy_e.pdf (accessed June 2 2003)

27 Wong WM, Ho JC, Hung IF, Ng W, Lam YM, Tam WO, Wong BC, Wong PC, 
Lai CL, Lam WK et al (2003) Temporal patterns of hepatic dysfunction and disease severity in patients with SARS. JAMA 290: 2663-2665

28 Tsang OT, Chau TN, Choi KW, Tso YK, Lim W, Chiu MC, Tong WL, Lee PO, Lam BH, Ng TK et al (2003) Coronavirus-positive nasopharyngeal aspirate as predictor for severe acute respiratory syndrome mortality. Emerg Infect Dis 9: 1381-1387.

29 Chau TN, Lee KC, Yao H, Tsang TY, Chow TC, Yeung YC, Choi KW, Tso YK, Lau T, Lai ST et al (2004) SARS-associated viral hepatitis caused by a novel coronavirus: report of three cases. Hepatology 39(2): 302-310

30 Wong RS, Wu A, To KF, Lee N, Lam CW, Wong CK, Chan PK, Ng MH, Yu LM, Hui DS et al (2003) Haematological manifestations in patients with severe acute respiratory syndrome: retrospective analysis. BMJ 326: 1358-1362

31 Wang JL, Wang JT, Yu CJ, Chen YC, Hsueh PR, Hsiao CH, Kao CL, Chang SC, Yang PC (2003) Rhabdomyolysis associated with probable SARS. Am J Med 115: 421-422

32 Li SS, Cheng CW, Fu CL, Chan YH, Lee MP, Chan JW, Yiu SF (2003) Left ventricular performance in patients with Severe Acute Respiratory syndrome-a 30-day echocardiographic follow-up study. Circulation 108: 1798-1803

33 Lau KK, Yu WC, Chu CM, Lau ST, Sheng B, Yuen KY (2004) Possible central nervous system infection by SARS coronavirus. Emerg Infect Dis 10: 342-344

34 Arbour N, Talbot PJ (1998) Persistent infection of neural cell lines by human coronaviruses. Adv Exp Med Biol 440: 575-581

35 Lee HK, Tso EY, Chau TN, Tsang OT, Choi KW, Lai TS (2003) Asymptomatic severe acute respiratory syndrome-associated coronavirus infection. Emerg Infect Dis 9: 1491-1492

36 Chow PK, Ooi EE, Tan HK, Ong KW, Sil BK, Teo M, Ng T, Soo KC (2004) Healthcare worker seroconversion in SARS outbreak. Emerg Infect Dis 10: 249-250

37 Li G, Zhao Z, Chen L, Zhou Y (2003) Mild severe acute respiratory syndrome. Emerg Infect Dis 9: 1182-1183

38 Lin M, Tseng HK, Trejaut JA, Lee HL, Loo JH, Chu CC, Chen PJ, Su YW, Lim KH, Tsai ZU et al (2003) Association of HLA class 1 with severe acute respiratory syndrome coronavirus infection. Available from: http://www.biomedcentral.com/1471-2350/4/9 (Accessed Dec 6, 2003)

39 Chiu WK, Cheung PC, Ng KL, Ip PL, Sugunan VK, Luk DC, Ma LC, Chan BH, Lo KL, Lai WM (2003) Severe acute respiratory syndrome in children: experience in a regional hospital in Hong Kong. Pediatr Crit Care Med 4: 279-283

40 Hon KL, Leung CW, Cheng WT Chan PK, Chu WC, Kwan YW, Li AM, Fong $\mathrm{NC}, \mathrm{Ng}$ PC, Chiu MC et al (2003) Clinical presentations and outcome of severe acute respiratory syndrome in children. Lancet 361: 1701-1703

41 Tee AK, Oh HML, Hui KP, Lien CT, Narendran K, Heng BH, Ling AE (2004) Atypical SARS in geriatric patient. Emerg Infect Dis 10:261-264

42 Tsui PT, Kwok ML, Yuen H, Lai ST (2003) Severe acute respiratory syndrome: clinical outcome and prognostic correlates. Emerg Infect Dis 9:1064-1069

43 Chan JW, Ng CK, Chan YH, Mok TY, Lee WH, Lee S, Chu SY, Law WL, Lee 
MP, Li PCl (2003) Short term outcome and risk factors for adverse clinical outcomes in adults with severe acute respiratory syndrome (SARS). Thorax 58: 686-689

44 Wang H, Ding Y, Li X, Yang L, Zhang W, Kang W (2003) Fatal aspergillosis in a patient with SARS who was treated with corticosteroids. $N$ Engl J Med 349: 507-508

45 World Health Organization (2003) Summary of probable SARS cases with onset of illness from 1 Nov 2002 to 31 July 2003. Available from: http://www.who.int/csr/sars/country/table2004_04_21/en/ (Accessed Dec 6, 2003)

46 Rainer TH, Cameron PA, Smit D, Ong KL, Ng AW, Chan DP, Ahuja AT, Chan LY, Sung YY et al (2003) Evaluation of WHO criteria for identifying patients with severe acute respiratory syndrome out of hospital: prospective observational study. BMJ 326: 1354-1358

47 Zou Z, Yang Y, Chen J, Xin S, Zhang W, Zhou X, Mao Y, Hu L, Liu D, Chang $B$ et al (2004) Prognostic factors for severe acute respiratory syndrome: a clinical analysis of 165 cases. Clin Infect Dis 38: 483-489

48 Ng EK, Hui DS, Chan KC, Hung EC, Chiu RW, Lee N, Wu A, Chim SS, Tong YK, Sung JJ et al (2003) Quantitative analysis and prognostic implication of SARS coronavirus RNA in the plasma and serum of patients with severe acute respiratory syndrome. Clin Chem 49: 1976-1980

49 Grant PR, Garson JA, Tedder RS, Chan PK, Tam JS, Sung JJ (2003) Detection of SARS Coronavirus in Plasma by Real-Time RT-PCR. $N$ Engl J Med. 349: 2468-2469

50 Chau TN, Lee PO, Choi KW, Lee CM, Ma KF, Tsang TY, Tso YK, Chiu MC, Tong WL, Yu WC et al (2004) Value of initial chest radiographs for predicting clinical outcomes in patients with severe acute respiratory syndrome. Am J Med 117(4): 249-254 